\title{
KIAI SEBAGAI PATRON DAN SPONSOR PRAKTIK MULTILITERASI DI PESANTREN PADA ERA MEDIA DIGITAL
}

\section{KIAI AS A PATRON AND SPONSOR FOR MULTILITERACIES PRACTICE IN PESANTREN IN DIGITAL MEDIA ERA}

\author{
Agus Iswanto \\ Balai Litbang Agama Semarang, Badan Litbang dan Diklat Kementerian Agama \\ email: agus.iswanto83@gmail.com
}

Naskah Diterima: 6 September 2019; Direvisi: 25 Februari 2020; Disetujui: 16 Desember 2020

\begin{abstract}
Literacy is no longer single entity; there are several aspects of literacies, especially in the era of information technology and digital media today, so it is called multiliteracies. This article presents the results of research on multiliteracies practice products in the form of Islamic boarding school (pesantren) website. Applying the theoretical framework of the new literacy study approach, this research focuses on the context, patron, or sponsorship of multiliteracy practices, and santri responses through it. Data were collected through textual analysis, interviews, and observations at the Nuris Pesantren in Jember. The results showed that patrons of the pesantren multiliteracies practice that produced website were the kiai and the sons of the kiai. Literacy patrons or sponsors always color the content and cultivation of any web or multiliteracies product. Kiai pesantren holds positions as patron and sponsor of pesantren-based multiliteracy practices in the age of digital media technology. The kiai's vision and thought have an influence on the practice and products of pesantren multiliteracies. The kiai serves as a model (patron) of literacy as well as a sponsor (supporting element) of multiliteracy practices. The kiai remains a "filter" of values for the santri and the community in the digital era.
\end{abstract}

Keywords: Multiliteracies, pesantren, kiai, literacy patron, literacy sponsor

\begin{abstract}
Abstrak
Literasi kini tidak lagi satu, tetapi beberapa aspek, terlebih di era teknologi informasi dan media digital, sehingga disebut dengan multiliterasi. Tulisan ini menyajikan hasil penelitian tentang produk praktik multiliterasi yang berupa website pondok pesantren. Dengan menerapkan kerangka teoritik pendekatan kajian literasi baru, penelitian ini memfokuskan bahasan pada konteks, patron, atau sponsor yang membentuk produk praktik multiliterasi, serta respon santri terhadap praktik tersebut. Data dikumpulkan dengan telaah dan analisis tekstual, wawancara, dan observasi di Pondok Pesantren Nuris Jember. Hasil penelitian menunjukkan bahwa patron atau sponsor praktik multiliterasi pesantren yang menghasilkan produk website adalah kiai dan putra-putra kiai. Patron atau sponsor literasi senantiasa mewarnai konten dan penggarapan website atau produk multiliterasi apapun. Kiai pesantren memegang posisi sebagai patron dan sponsor praktik multiliterasi berbasis pesantren di zaman teknologi media digital. Visi kiai dan pemikirannya memberikan pengaruh pada praktik dan produk literasi/multiliterasi pesantren. Kiai menjadi teladan (patron) literasi sekaligus juga menjadi sponsor (unsur yang mendukung) praktik multiliterasi. Namun, kiai tetap menjadi "penyaring" nilai bagi santri dan masyarakat di tengah revolusi teknologi digital.
\end{abstract}

Kata kunci: Multiliterasi, pesantren, kiai, patron literasi, sponsor literasi 


\section{PENDAHULUAN}

Organisasi dunia untuk pendidikan, ilmu pengetahuan, dan kebudayaan (UNESCO) telah menyampaikan tentang beberapa hasil studi yang menunjukkan manfaat positif literasi, baik secara individual, politik, budaya, sosial, maupun ekonomi (Burnett et al., 2006). Manfaat literasi yang terdapat di seluruh kehidupan manusia tentu mengandaikan adanya kompleksitas keterampilan literasi. Oleh karena itu literasi sekarang ini tidak lagi dapat dipahami sebatas "melek aksara" atau kemampuan membaca. Kemampuan literasi berkembang lebih kompleks seiring dengan kompleksitas perkembangan moda komunikasi dan teknologi informasi di era digital.

Meningkatnya kompleksitas komunikasi terkini menimbulkan sejumlah kemampuan berbeda dan lebih kompleks yang harus dimiliki pula. Kemampuan lintas literasi ini kemudian disebut dengan literasi abad ke-21. Literasi abad ke-21 disebut juga 'multiliterasi' (multiliteracies), atau juga disebut dengan 'literasi baru' (new literacy). Keterampilan multiliterasi ini meliputi literasi visual, literasi informasi, literasi budaya, dan literasi digital. Istilah ini diajukan oleh sebuah kelompok sarjana yang bernama The New London Group (1996) sebagai respon tentang perkembangan di abad 21 terkait dengan literasi. Kelompok sarjana ini meyakini bahwa literasi dalam beragam bentuk (multiliterasi) sekarang ini diperlukan, baik di sekolah maupun di masyarakat.

Studi-studi literasi kini di dunia juga mulai berkembang ke arah multiliterasi. Beberapa penelitian terfokus pada salah satu aspek multiliterasi, seperti literasi visual (Trumbo, 1999; Lewis, 2004; Mansyur, Rahamma and Fatima, 2013; 'Literasi Visual Tokoh Hanoman Bali dengan Pendekatan Augmented Reality', 2016), praktik literasi digital anak-anak dan kaum muda baik di sekolah maupun masyarakat(Mills, 2010; Marsh, 2011; Chassiakos et al., 2016; Masyhur, 2016; Yanti, 2016), dan multiliterasi kompleks yang menggabungkan teks online, video games dan komputer (Pasadas, 2010; Beavis, Muspratt and Thompson, 2015). Studi praktik multiliterasi juga dilakukan dalam konteks pembelajaran di sekolah (Unsworth, 2002;
Jewitt, 2008; Abidin, Mulyati and Yunansah, 2017a; Susilo and Ramdiati, 2019).

Studi tentang praktik multiliterasi di lembaga pesantren belum banyak dilakukan. Kesan umum yang diajukan adalah bahwa pesantren pada dasarnya telah mempraktikan literasi, karena sehari-sehari para santri sudah belajar dengan teks, khususnya teks-teks keislaman yang disebut dengan "kitab kuning." Jadi, sudah tentu para santri mempraktikan literasi, khususnya literasi keagamaan. Penelitian lain menunjukkan bahwa tradisi menulis ilmiah (salah satu bagian dari literasi) santri masih kurang (Murtadlo, 2019). Namun bagaimana dengan praktik literasi yang tidak hanya terbatas pada teks bacaan tercetak semata, atau praktik literasi pesantren dalam dunia digital? Beberapa pondok pesantren memang sudah dan mulai beradaptasi dengan perkembangan teknologi informasi atau teknologi informasi dan komputer (Mastiyah, 2018, pp. 2-32), misalnya dengan menghadirkan situs-situs online atau website yang memberikan informasi seputar pesantrennya dan tulisan-tulisan lain dari para santri sendiri sebagai media ekspresi dan pembelajaran. Namun, hal itu luput dari perhatian para peneliti di bidang kajian literasi dan multiliterasi.

Penguatan multiliterasi di lembaga pendidikan kini mulai perlu diperhatikan mengingat kompleksitas permasalahan kehidupan yang muncul, termasuk di dalamnya lembaga pendidikan pesantren yang menjadi lembaga pendidikan Islam yang penting dan khas di Indonesia. Apakah multiliterasi sudah dipraktikan di lembaga-lembaga pendidikan Islam seperti pesantren? Jika sudah bagaimana bentuk dan polanya? Apa peluang dan tantangan praktik multiliterasi di pesantren? Demikian beberapa pertanyaan yang mengemuka tentang praktik literasi dan multiliterasi di lembaga pendidikan Islam.

Artikel ini hendak menyajikan hasil penelitian tentang praktik multiliterasi di sebuah pondok pesantren, khususnya tentang peran dan representasi kiai yang disebut sebagai unsur penting dalam pesantren (Dhofier, 1994; Lukens-Bull, 2001a). Pertanyaan-pertanyaan penelitian dalam tulisan ini adalah: bagaimana praktik multiliterasi di pesantren diwujudkan? 
Bagaimana peran atau representasi kiai sebagai unsur penting pesantren dalam praktik multiliterasi tersebut? Aspek-aspek yang dibahas dalam artikel ini adalah mengenai bentuk praktik multiliterasi yang diwujudkan, konteks praktik literasi, dan patron/sponsor praktik literasi. Penelitian ini mengambil fokus website sebagai salah satu bentuk media digital yang dapat menampung konsep multiliterasi (Dewayani, 2017). Analisis terutama difokuskan pada aspek konteks, patron dan sponsor multiliterasi.

Penelitian tentang praktik multiliterasi ini penting untuk melihat upaya-upaya yang dilakukan atau tidak dilakukan oleh pesantren sekarang ini, khususnya yang terkait dengan perubahan revolusi digital. Studi-studi yang ada tentang pesantren masih terbatas pada permasalahan pesantren dan kiai menghadapi tantangan modernisasi dan globalisasi secara umum (Lukens-Bull, 2000). Oleh karena itu hasil penelitian ini diharapkan dapat menyumbang pada pengetahuan tentang perubahan dan keberlanjutan pesantren dalam kurun perkembangan teknologi digital. Lebih khusus, hasil penelitian ini diharapkan dapat menyumbang bagi pengetahuan dan diskusi tentang peran kiai dalam era multiliterasi dan teknologi media digital di pesantren.

\section{KAJIAN TEORI}

Studi tentang praktik literasi di pesantren yang ada biasanya terkait dengan penggunaan kitab-kitab dan praktik pembelajaran. Hal tersebut seperti yang dikemukakan oleh Dhofier (1994) dan Lukens-Bull (Lukens-Bull, 2000, 2001b). Ada juga beberapa kajian tentang pesantren yang dikaitkan dengan perkembangan teknologi digital (Lubis et al., 2009; Jamaludin, 2012; Gazali, 2018; Halim, 2018) Kajian tentang pesantren, terutama peran kiai dalam praktik multiliterasi belum banyak diperhatikan oleh para sarjana. Studi peran dan representasi kiai dalam praktik multiliterasi pesantren dapat dilakukan dengan pendekatan "kajian literasi baru," hal itu karena pendekatan ini lebih mempersoalkan relasi konteks, patron dan produk literasi (The London Group, 1996). Namun, sebelum menyampaikan pendekatan tersebut, terlebih dahulu perlu penulis sampaikan konsep multiliterasi hingga sampai kemunculan pendekatan baru tersebut.
Istilah multiliterasi digunakan untuk merespon perkembangan keberagaman (multiplicity) saluran-saluran komunikasi informasi dan pengetahuan yang saling terintegrasi dalam perubahan global kebudayaan. Keberagaman saluran komunikasi yang terintegrasi tampak dalam teks yang terkait dengan aspek visual, audio, spasial, sikap, dan perilaku. Ketika teknologi saluran komunikasi tersebut berubah cepat, maka tentu sudah tidak lagi bisa dihadapi dengan satu pengetahuan dan keterampilan saja (single literacy atau literacy), tetapi perlu dihadapi dengan apa yang disebut dengan multiliterasi (multiliteracies) (The London Group, 1996, p. 64). Dengan pandangan seperti ini, literasi melibatkan lebih dari satu pengetahuan dan keterampilan yang harus dipelajari, baik melalui format cetak atau online.

Adapun aspek-aspek kecakapan atau keterampilan dalam multiliterasi sebagai berikut, yaitu (1) mengembangkan kecakapan dan keterampilan penggunaan alat-alat teknologi media digital; (2) membangun jaringan dengan orang lain untuk menyelesaikan masalah secara kolaboratif dan lintas budaya; (3) mendesain dan berbagi informasi dengan komunitas global untuk berbagai tujuan; (4) mengolah, menganalisis, dan mensintesis semua informasi dalam berbagai media; (5) menciptakan, mengkritik, menganalisis, dan mengavaluasi teks-teks multimedia; (6) bertanggungjawab secara etika (Lankshear and Knobel, 2011, p. 25).

Multiliterasi mengacu pada keterampilanketerampilan yang harus dikuasai seseorang, termasuk di dalamnya pembelajar atau siswa, untuk menghadapi dan memenuhi kebutuhan hidup sehari-sehari mereka. Keterampilanketerampilan tersebut mencakup literasi dasar dan kompetensi atau kualitas karakter. Literasi dasar mencakup enam aspek, yakni literasi membaca dan menulis, numerik atau matematis, literasi sains, literasi teknologi informasi dan komputer, literasi finansial, literasi kewargaan dan literasi budaya. Keenam literasi tersebut disebut dengan literasi dasar, karena sesungguhnya merupakan keterampilanketerampilan dasar yang harus dimiliki oleh seorang siswa untuk menghadapi tantang 
kehidupan abad 21 (World Economic Forum, 2016).

Hal tersebut juga sesuai dengan kerangka Partnership for $21^{\text {st }}$ Century Skills, suatu lembaga di bawah UNESCO. Lembaga tersebut telah mengajukan sebuah kerangka pembelajaran di abad 21. Kerangka tersebut mendeskripsikan keterampilan, pengetahuan, dan keahlian-keahlian yang harus dimiliki oleh siswa untuk menghadapi tantangan kehidupan di abad ke-21. Kerangka tersebut terdiri dari (1) subyek inti; (2) keterampilan pembelajaran dan inovasi yang mencakup kreativitas dan inovasi, berpikir kritis dan pemecahan masalah, komunikasi dan kolaborasi; (3) keterampilan teknologi informasi dan media, yang mencakup literasi informasi, literasi media, serta literasi teknologi informasi dan komunikasi; (4) keterampilan hidup dan karir yang mencakup karakter fleksibilitas dan mampu beradaptasi, inisiatif dan mandiri, keterampilan bersosialisasi dalam lintas budaya, produktifitas dan akuntabilitas, kepemimpinan dan tanggungjawab (The Partnership for 21st Century Skills, 2009).

Karena muncul kesadaran akan perlunya multiliterasi yang peka terhadap keberagaman saluran komunikasi dan keberagaman budaya karena globalisasi, maka para sarjana di bidang kajian literasi mengajukan suatu pendekatan teoritis baru dalam meneliti praktik literasi. Pendekatan teoritis itu disebut dengan pendekatan "literasi baru" atau "the new literacy/literacies. " Pendekatan ini dapat dilihat dalam dua sisi, yakni: sisi paradigmatik dan sisi ontologik (Lankshear and Knobel, 2011).

Sisi paradigmatik kajian literasi baru, sebagaimana diajukan oleh beberapa sarjana (Gee, 2000; Street, 2001, pp. 1-18), mengacu pada pendekatan sosiokultural tertentu untuk memahami dan meneliti literasi. "Kajian literasi baru" dapat dilihat sebagai paradigma teoretis dan penelitian baru untuk melihat masalah literasi. Para pendukung kajian literasi baru menganggap proyek mereka terdiri dari paradigma baru dan berbeda dengan pendekatan pendekatan dominan yang ada (Lankshear and Knobel, 2011).

Paradigma 'baru' dalam kaitannya dengan literasi memandang praktik literasi sebagai fenomena sosial. Artinya, meneliti praktik literasi dari perspektif sosio-kultural. Meneliti praktik literasi dengan paradigma sosio-kultural adalah melihat kemungkinankemungkinan orang dalam menegosiasikan makna dalam praktik literasi tersebut. Negosiasi ini melibatkan nilai-nilai, pandanganpandangan atau ideologi yang dianut oleh orang atau komunitas yang melakukan praktik literasi (Jewitt, 2008). Oleh karena itu, selain disebut dengan pendekatan kontekstual, karena mempertimbangkan aspek sosio-kultural dan ideologi, maka biasa disebut juga dengan "pendekatan model ideologis dan sosiokultural" terhadap praktik literasi. Pendekatan yang disebut terakhir biasa dibedakan dengan pendekatan model otonom, yakni memandang literasi secara otonom (secara mandiri) memengaruhi kognisi dan praktik sosial. Sementara itu, pendekatan model ideologis dan sosio-kultural atau kontekstual memandang bahwa literasi adalah praktik sosial, bukan sekadar keterampilan teknis dan netral. Praktik literasi terkait konstruksi secara sosial, yakni tentang cara orang mengakses pengetahuan, atau cara orang membaca dan menulis yang berakar pada konsepsi pengetahuan, identitas, dan kenyataan (Street, 2001).

Kajian praktik multiliterasi dengan perspektif kajian literasi baru memandang bahwa praktik literasi dibentuk oleh institusi sosial dan relasi kekuasaan. Sebagian relasi dianggap lebih dominan dan berpengaruh dibandingkan literasi yang lain (Dewayani and Retnaningdyah, 2017, p. 12). Karena terkait dengan relasi kekuasaan, kajian praktik literasi baru juga melihat sponsor dan patron yang memungkinkan praktik literasi terwujud. Patron literasi adalah panutan atau figur teladan literasi dalam suatu komunitas (Dewayani and Retnaningdyah, 2017, p. 44). Sedangkan sponsor literasi adalah sesuatu atau seseorang yang memampukan, mendukung, mengajarkan, dan menjadi model, selain juga sebagai pengatur praktik literasi (Brandt, 2001, p. 19). Kajian praktik literasi dengan perspektif kajian literasi baru ini juga melihat konteks dan motif praktik literasi yang diaktualisasikan oleh patron/sponsor praktik literasi.

\section{METODOLOGI}

Penelitian ini dilakukan dengan pendekatan kualitatif. Artinya, penelitian ini 
tidak berupaya untuk melakukan generalisasi, tetapi mencari pola-pola praktik literasi, khususnya terkait dengan masalah patron dan sponsor, yang dapat dijadikan pelajaran (lesson learned) bagi kasus yang sama di tempat-tempat lain. Hal ini juga yang menjadi salah satu ciri khas kajian praktik literasi baru yang lebih banyak menggunakan pendekatan kualitatif.

Fokus penelitian ini adalah website yang diproduksi oleh sebuah pesantren di Kabupaten Jember, yakni Pesantren Nuris. Pondok Pesantren ini terletak di Jalan Pangandaran 48, Antirogo, Sumbersari, Jember. Website, atau web dalam bahasa Indonesia, adalah sebuah jaringan informasi dokumen hipertuatan (sebuah istilah dalam teknologi digital yang menunjukkan hubungan antara elemen kata, simbol, gambar, dalam dokumen dengan dokumen yang sama atau berbeda; sebuah istilah dalam bahasa internet), yang bisa diakses dan diunduh yang terdapat dalam komputer yang dihubungkan dengan internet. Sekarang ini web tidak hanya dihubungkan dengan komputer, tetapi juga gawai pintar. Sebagaimana pengertiannya, web adalah kumpulan halaman-halaman yang digunakan untuk menampilkan informasi teks, gambar gerak atau diam, animasi, suara, dan atau gabungan dari semuanya, baik yang sifatnya statis maupun dinamis, semuanya itu membentuk satu rangkaian atau jaringan bangunan yang saling terkait. Hubungan antara satu halaman web dengan halaman web lainnya disebut hyperlink, sedangkan hubungan antara satu teks dengan teks lainnya dalam halaman web lain disebut dengan hypertext. Berdasarkan pengertian ini saja, web sudah memenuhi unsur multiliterasi. Perkembangan terkini dari web adalah blog, yakni media sosial yang memungkinkan penggunanya untuk mengunggah aktivitas keseharian, saling mengomentari, dan berbagi, baik berupa tautan web lain maupun informasi lainnya (Nasrullah, 2017, p. 41).

Untuk mengumpulkan dan menganalisis data yang terdapat dalam web, penelitian ini menggunakan metode analisis tekstual terhadap web pesantren dengan alamat www.pesantrennuris.net. Tujuan analisis tekstual dalam penelitian ini adalah untuk mengetahui bagaimana Pesantren Nuris mempraktikan multiliterasi sebagaimana yang tampak dalam web. Unit analisis dalam analisis tekstual penelitian ini adalah sesuai dengan kerangka teori di atas.

Website digunakan sebagai obyek utama penelitian adalah karena "teks" web tersebut menyediakan data yang diperlukan. Data tersebut mulai dari konteks sejarah, pemikiran, hingga variasi genre, tema, dan menu informasi yang diperlukan untuk mengeksplorasi masalah penelitian. Namun, untuk melengkapi data yang tersedia dalam web, penelitian ini juga melakukan observasi dan wawancara di lokasi pesantren. Lokasi pesantren ini tidak jauh dari pusat kota kabupaten. Pondok pesantren ini dipilih karena sudah menggabungkan sistem pendidikan tradisional dan modern, yakni pengajian kitab kuning dan sekolah klasikal dalam satu lembaga. Selain itu, pesantren ini belum banyak dijadikan obyek penelitian, apalagi terkait dengan praktik literasi, tidak seperti pesantren-pesantren terkenal lainnya di wilayah "tapal kuda" atau Jawa Timur bagian timur.

Pengumpulan data di lokasi pesantren dilakukan dengan wawancara, observasi, dan telaah pustaka atau dokumen. Wawancara dilakukan untuk mendapatkan data tentang konteks sejarah perkembangan kelembagaan dan konteks pemikiran atau ideologi. Wawancara dilakukan kepada para informan yang dipandang dapat memberikan data tentang topik yang sedang diteliti. Informan-informan kunci yang dijadikan sasaran wawancara adalah pengasuh atau kiai, putra-putra kiai pengasuh, ustaz-ustaz pesantren, dan perwakilan siswa atau santri. Wawancara dengan pengasuh atau kiai, putra-putra pengasuh atau kiai, dan ustazustaz untuk mendapatkan tambahan data tentang sejarah perkembangan lembaga pesantren, patron atau sponsor literasi serta konteks atau pemikirannya. Sedangkan wawancara dengan perwakilan siswa atau santri, atau juga alumninya dimaksudkan untuk mendapatkan data tentang proses dan produk literasi. Santri atau siswa yang dijadikan wawancara adalah mereka yang berada di jenjang menengah atas, baik Madrasah Aliyah (MA), maupun di Sekolah Menengah Atas (SMA). Hal ini karena menurut studi awal, 
siswa atau santri yang aktif dalam praktik literasi media adalah di jenjang tersebut.

Selain dengan wawancara, pengumpulan data dilakukan dengan observasi. Observasi dilakukan untuk mengumpulkan data konteks sosial dan budaya pesantren yang menjadi latar praktik multiliterasi. Observasi diarahkan pada aktivitas praktik literasi dan proses-proses yang terjadi ketika menghasilkan produk literasi. Observasi dilakukan tidak terbatas pada saatsaat kegiatan pembelajaran di sekolah formal maupun di pesantren, tetapi diupayakan dalam semua aktivitas siswa atau santri. Observasi tidak hanya dilakukan terhadap aktivitas santri, tetapi juga ustaz maupun para dewan pengasuh (putra-putra kiai).

Setelah pengumpulan data, langkah selanjutnya adalah analisis data. Analisis data dilakukan dengan proses reduksi, penyajian, dan penarikan simpulan (Miles dan Huberman, 1994: 10-12). Reduksi data dilakukan dengan menyeleksi data, memfokuskan temuan, penyederhanaan, dan transformasi data sesuai dengan tema-tema yang diajukan dalam kerangka teoritik kajian literasi baru yang digunakan. Setelah direduksi, peneliti melakukan penyajian data sehingga dapat dilakukan penarikan simpulan. Upaya interpretasi data sebagai langkah akhir analisis data dilakukan dengan melakukan perbandingan dan sintesis dengan literaturliteratur atau hasil-hasil penelitian lain sebagaimana disarankan oleh Creswell (2016: 284).

\section{HASIL DAN PEMBAHASAN}

Website Pondok Pesantren Nuris mulai hadir pada 2016. Ada banyak menu dalam web Pondok Pesantren Nuris, mulai dari halaman depan, berita, tausiyah pengasuh, sejarah, prestasi, pojok alumni, kolom, Islamic studies, bahstul masail, sastra, tokoh, wawancara, bedah buku, galeri foto, fasilitas, dan hubungi kami. Dapat dikatakan, web ini memuat hampir semua aktivitas pesantren dan lembaga-lembaga pendidikan formalnya, tulisan-tulisan yang masuk dalam menu-menu tertentu yang ditulis oleh para santri maupun alumni. Tidak ada keterangan pengelola web ini, dan tidak ada susunan redaksi yang ditampilkan. Namun, menurut keterangan salah seorang ustaz dan pengelola web bahwa pengelola dan redaksi web adalah para santri pesantren yang sekolah di SMA, MA, dan SMK yang tergabung dalam kelompok ekstra jurnalistik (wawancara dengan F, 3/10/2018; wawancara dengan A, 4/9/2019).

Setiap tulisan yang muncul di halaman depan selalu diberi keterangan tulisan tersebut masuk dalam menu apa. Halaman depan web memuncukan informasi terbaru dan terpopuler. Setiap tulisan diberi keterangan siapa yang menulis baik secara lengkap maupun inisial. Semua tulisan juga melalui proses editing yang tampak dicantumkan dalam setiap tulisan.

\section{Konteks Praktik Pembelajaran Multiliterasi}

\section{Konteks Sejarah Pendirian Pesantren}

Konteks sejarah ini disampaikan dalam website Pondok Pesantren Nuris, oleh karena itu, penulis banyak mengacu pada website tersebut. Pondok Pesantren Nuris didirikan pada 1981 oleh KH. Muhyuddin Abdusshomad. Santri pesantren ini di awal berdirinya hanya berjumlah belasan orang. Santri-santri ini belajar agama secara langsung kepada sang kiai, semacam "ngaji sorogan" (santri mengaji langsung kepada kiai dengan membacakan sebuah kitab tertentu dan kiai menyimak, membenarkan, menjelaskan) atau "bandongan" (kiai atau guru membacakan kitab tertentu, sementara santri mendengarkan sambil menuliskan makna dalam kitab). Beberapa santri tersebut adalah juga mahasiswa di Universitas Jember (UNEJ).

Karena langkanya sekolah formal berciri khas Islam di lingkungan Kiai Muhyuddin, maka pada tahun 1983, dia mendirikan Sekolah Menengah Pertama (SMP) Nuris. Didirikannya sekolah ini selain untuk menampung lulusan sekolah dasar yang ada di sekitar lingkungannya, juga sebagai upaya menjadikan pesantren tidak hanya tempat belajar ilmu agama, tetapi juga ilmu-ilmu pengetahuan yang lain. Jadi, sekolah formal pertama yang didirikan adalah SMP, bukan SD atau MI.

Setelah mendirikan SMP, Kiai Muhyiddin mendirikan SMA, yakni pada tahun 1989. Hal ini karena banyak wali santri atau murid SMP yang menginginkan anaknya untuk tetap melanjutkan belajar di pesantren yang sama. Keberadaan SMA Nuris di dalam pondok 
pesantren menjadi sejalan dengan tujuan awal didirikannya SMP, yakni menjadi tempat santri atau siswa belajar ilmu-ilmu agama dan umum sekaligus. Santri belajar tentang ilmu-ilmu keislaman di pesantren, dan belajar ilmu-ilmu pengetahuan umum di sekolah.

Setelah kepulangan salah satu putra Kiai Muhyuddin, yakni Robith Qoshidi, dari Universitas Al-Azhar Kairo Mesir pada Desember 2007, muncul gagasan untuk mendirikan Madrasah Tsanawiyah (MTs). Hal ini dilatarbelakangi oleh keinginan menciptakan sebuah lembaga pendidikan yang memiliki keunggulan dalam bidang kitab kuning dan sains sekaligus, serta teguh memegang prinsip Ahlusunnah Wal Jama'ah (Aswaja). Kurikulum MTs Nuris adalah perpaduan kurikulum Al-Azhar Kairo Mesir dan Kementerian Agama. Kurikulum ini disusun agar siswa-siswa MTs memiliki kompetensi dalam pembelajaran agama berbasis kitab kuning, menguasai sains dan teknologi, dan memiliki argumentasi yang kokoh untuk akidah dan amaliyah Aswaja. Untuk memperkuat pengembangan kitab kuning, maka dibentuklah MPKiS (Manajemen Pengembangan Kitab Kuning Santri). Lembaga ini didirikan untuk mengontrol perkembangan setiap siswa agar mampu membaca kitab kuning.

Dengan berdirinya MTs, maka diperlukan suatu lembaga yang mampu menampung lulusannya. Oleh karena itu, Kiai Muhyuddin dan putranya, Robith Qoshidi, mendirikan Madrasah Aliyah (MA) Nuris pada tahun 2011. Tujuan pendirian madrasah ini adalah seperti ketika mendirikan MTs, hanya saja dilakukan pada jejang yang lebih tinggi. Seluruh siswa MA harus tinggal di asrama pondok pesantren. Kurikulum keagamaan MA dikelola dalam MPKiS. Siswa-siswa atau santri-santri MA mempelajari ilmu-ilmu keislaman dengan berbasiskan kitab kuning, yakni ilmu nahwu menggunakan kitab Alfiyah, ilmu fikih menggunakan kitab Fathul Qarib, ilmu usul fikih menggunakan kitab Waraqat, ilmu hadis menggunakan kitab Mandumah Baiquniyah, dan Aswaja menggunakan kitab al-Hujaj alQath'iyyah karya Kiai Muhyuddin sendiri. Tidak hanya penguasaan kitab kuning, MA Nuris juga mengembangan program penghafalan Alquran dengan mendirikan MHQ (Madrasah Huffadz al-Qur'an).

Selain penguasaan ilmu-ilmu keislaman, MA Nuris juga mengembangkan pembelajaran sains. Oleh karena itu didirikan lembaga Madrasah Sains. Pengembangan sains ini dilakukan pada sore hari setelah jam belajar pagi hari. Jadi, siswa-siwa yang aktif di lembaga ini diorientasikan untuk mengikuti lomba-lomba ilmiah seperti Kompitisi Sains Madrasah (KSM).

Selain mempersiapkan siswa yang ahli di bidang agama dan sains, Pondok Pesantren Nuris juga berupaya menyiapkan lulusan yang siap kerja. Karena itu, pada tahun 2003, Pondok Pesantren Nuris mendirikan Sekolah Menengah Kejuruan (SMK). Hal tersebut sebagai respon pengasuh atas program pemerintah yang meluncurkan program "SMK Bisa." Ada dua jurusan di SMK Nuris, yakni jurusan Teknik Komputer dan Jaringan (TKJ), Teknik Sepeda Motor (TSM), dan Teknik Otomotif (TO). Siswa-siswa SMK Nuris pun tinggal di asrama pondok. Hal tersebut agar siswa mampu mengenali khazanah keilmuan Islam dan mempraktikan ilmu agama tersebut dalam kehidupan sehari-sehari.

\section{Pesantren Nuris dan Kesadaran Pembelajaran Multiliterasi}

Jika dilihat dengan kerangka pembelajaran abad ke-21 (Abidin, Mulyati and Yunansah, 2017b, p. 8), maka lembaga pendidikan yang didirikan oleh Pondok Pesantren Nuris telah memenuhi beberapa aspek tersebut. Hal tersebut dapat dilihat dengan dimulainya kesadaran untuk mendirikan lembaga sekolah formal (SMP) agar siswa tidak saja dapat belajar agama tetapi juga memiliki kemampuan dalam bidang ilmu pengetahuan umum. Hal tersebut juga tampak dalam pendirian SMA, MTs, dan MA. Bahkan, Pondok Pesantren Nuris telah melengkapi satu pengetahuan atau literasi yang tidak disebutan di atas, yakni literasi agama. Selain memenuhi literasi dasar, Pondok Pesantren juga memenuhi pembelajaran dengan kecakapan hidup yang siap bekerja, yakni dengan mendirikan SMK. Dapat dikatakan bahwa Pondok Pesantren Nuris telah menerapkan pembejaran multilierasi berbasis pesantren. Temuan aspek-aspek literasi 
abad 21 yang tampak dalam lembaga pendidikan di Pondok Pesantren Nuris dapat digambarkan dalam diagram berikut.

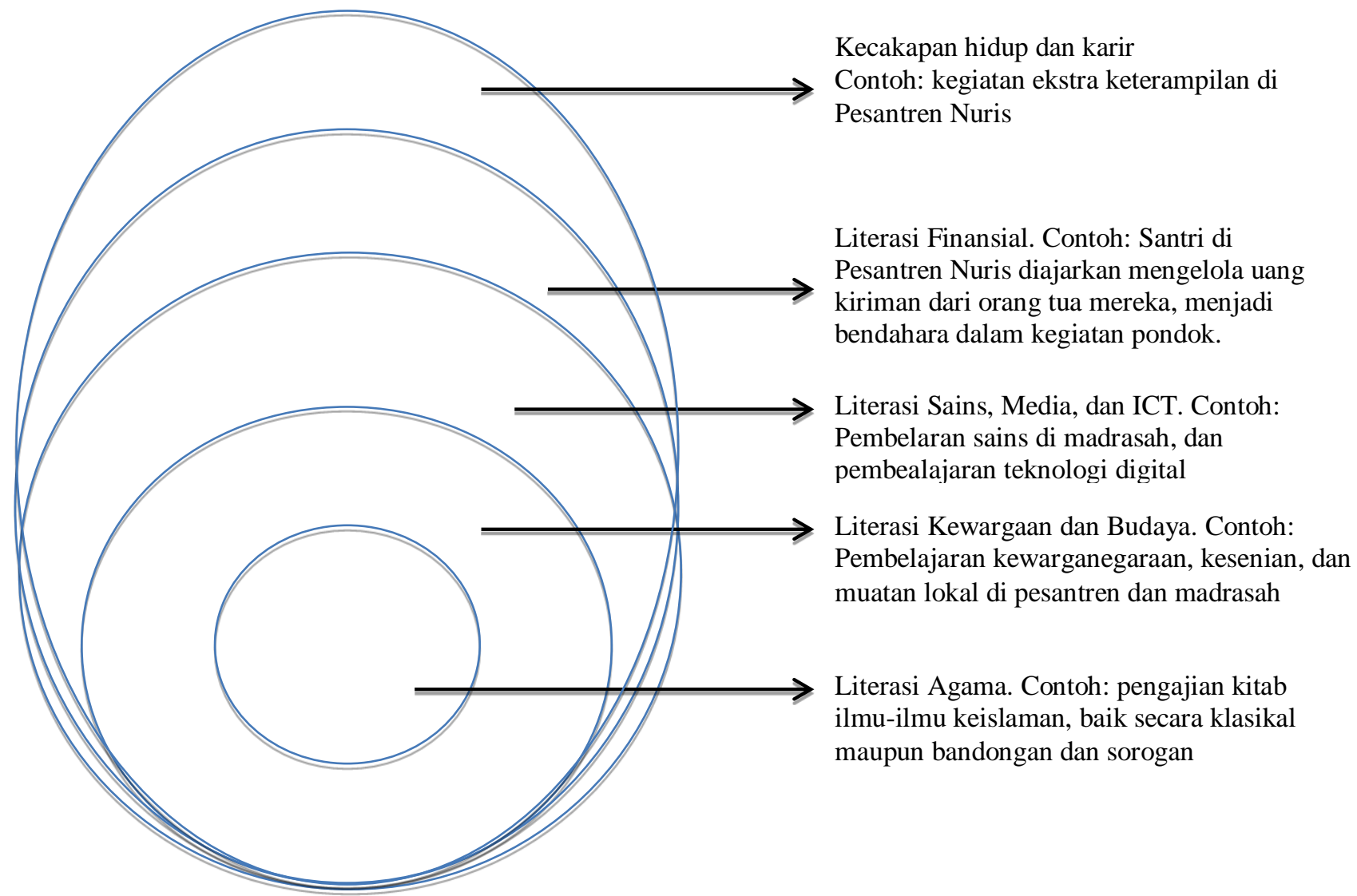

Gambar 1. Pembelajaran Multiliterasi Berbasis Pesantren (Pondok Pesantren Nuris)

Penerapan gambar di atas mengilustrasikan bahwa temuan literasi awal yang diajarkan adalah literasi agama, dan itu juga menjadi literasi inti dan dasar di Pesantren Nuris. Hal itu pula yang menjadi tujuan utama berdirinya Pondok Pesantren Nuris. Setelah itu, para santri saling belajar dengan sesamanya yang berasal dari latar belakang sosial-budaya yang berbeda. Para santri belajar menjadi sesama warga pesantren, warga sekolah, warga sesama daerah, warga sesama bangsa, dan akhirnya negara. Mereka saling belajar bergotong royong baik di asrama maupun sekolah. Hal tersebut kemudian menjadi sebuah pembelajaran literasi kewargaan dan budaya. Setelah itu, para santri di sekolah belajar berbagai macam ilmu pengetahuan (sains) (literasi sains), mereka dikenalkan juga dengan berbagai media, dan teknologi informasi dan komunikasi (literasi media, teknologi computer dan informasi). Selain itu mereka juga belajar mengatur keuangan sendiri, selain juga belajar ilmu ekonomi (literasi finansial).
Pondok Pesantren Nuris tidak hanya mempraktikan literasi dasar, tetapi juga menyediakan lembaga bagi para siswa atau santri yang ingin menempa keahlian hidup dan karir dengan mendirikan SMK, maka hal itu melengkapi aspek kecakapan hidup dan karir (kecakapan hidup/karir). Jadi, multiliterasi berbasis pesantren, sebagaimana yang dipraktikan oleh Pondok Pesantren Nuris, tidak hanya mengajarkan tetapi juga mempraktikan multiliterasi.

Praktik multiliterasi tersebut menghasilkan produk multiliterasi. Produkproduk tersebut dapat dilihat dari serangkaian prestasi atau hasil-hasil penelitan dalam KSM (Kompetisi Sains Madrasah). Namun, tulisan ini akan lebih mengkhususkan pembahasan pada produk multiliterasi yang dapat diamati dan dikaji dengan pendekatan kajian literasi baru. Produk tersebut adalah web. Produk web ini dipilih karena merepresentasikan praktik multiliterasi, yakni di dalamnya terkandung literasi agama, literasi kewargaan, literasi 
budaya, dan yang paling penting literasi media serta teknologi informasi dan komunikasi.

Website Pesantren Nuris mengindikasikan adanya kesadaran tentang kepentingan pembelajaran multiliterasi. Koordinator pengelola web mengatakan bahwa web itu didirikan atas inisiatif salah seorang putra Kiai Muhyiddin, yakni Robith Qoshidi pada tahun 2016. Hal tersebut karena dia memandang kebutuhan media digital yang lebih luas jangkauan dan variasi kontennya untuk masyarakat (wawancara dengan F, 4/9/2019). Kesadaran perlunya media digital adalah juga berarti kesadaran perlunya multiliterasi yang teraktualisasikan dalam website.

Deskripsi konteks pendirian unit-unit lembaga pendidikan di Pondok Pesantren Nuris ini sebetulnya merefleksikan kesadaran tentang pembelajaran multiliterasi di abad milenial. Hampir semua kecakapan hidup yang diperlukan oleh masyarakat milenial diakomodasi oleh pengasuh, dan hal tersebut didukung oleh anak-anaknya yang kemudian menjadi pengelola hampir semua lembaga pendidikan yang ada. Multiliterasi adalah suatu keadaan yang menggambarkan tentang keragaman literasi. Multiliterasi dirancang berdasarkan multikompetensi (Abidin, Mulyati and Yunansah, 2017b, p. 8).

\section{Pembatasan Akses Teknologi Digital}

Memang pesantren mendukung dan mengadakan pembelajaran teknologi informasi dan digital, bahkan sampai pada menghasilkan produk web sebagai salah sarana pembelajaran multilierasi dengan teknologi digital. Namun, hal itu juga tidak berarti para santri atau siswa bebas mengakses teknologi informasi digital setiap saat. "Ada aturan-aturan tertentu sehingga santri tidak bebas seterusnya untuk mengakses gawai", demikian yang diucapkan oleh salah seorang putra menantu Kiai Muhyiddin (wawancara dengan $\mathrm{Ab}$ dan $\mathrm{B}$, 2/10/2018).

Penggunaan gawai (handphone) oleh santri hanya dibolehkan saat-saat tertentu saja, seperti saat istirahat sekolah, maupun ngaji. Sedangkan pada saat belajar, baik di sekolah atau asrama, mereka dilarang untuk menggunakan gawai. Semua gawai santri dikumpulkan oleh pengurus asrama. Saat waktu istirahat malam pun para santri tidak diperkenankan menggunakan gawai. Meskipun demikian untuk kepentingan pembelajaran, para santri dibolehkan membawa laptop, tetapi laptop tersebut harus disimpan di ruang tertentu yang diawasi dan boleh digunakan saat-saat tertentu saja, itu pun dengan izin dan digunakan di ruang tertentu juga. Hal yang sama juga terjadi pada pembatasan akses internet Aksesakses internet hanya bisa dilakukan untuk kepentingan pembelajaran, seperti untuk mengerjakan tugas sekolah atau asrama. Akses internet pun dapat diizinkan di tempat khusus sehingga dapat diawasi oleh pengurus dan ustaz.

\section{Patron, Sponsor, dan Konteks Pemikiran}

Jelas dikemukakan bahwa inisiator web ini adalah Robith Qoshidi, putra kedua dari Kiai Muhyiddin. Oleh karena itu, dapat dikatakan bahwa dia adalah patron atau sponsor praktik multiliterasi. Namun yang lebih penting lagi adalah patron atau sponsor yang lebih atas, yakni pengasuh dan pendiri pesantren, yakni Kiai Muhyiddin. Untuk itu perlu dijelaskan bagaimana pemikiran sang sponsor ini.

Kiai Muhyiddin lahir di Jember pada 1955. Lahir dari keluarga kiai di Jember yang berdarah Madura. Sejak kecil belajar membaca Alquran kepada ayah dan ibunya sendiri di Pondok Pesantren Darussalam Jember. Kiai Muhyiddin mulai tahun 1966 hingga 1973 menjadi santri di Pondok Pesantren Raudlatul Ulum Sumber Wringin Jember di bawah asuhan KH. Umar dan KH. Khotib Umar. Selanjutnya pada tahun 1973 hingga 1980 belajar di sebuah pondok pesantren terkenal di Pasuruan, yakni Pondok Pesantren Sidogiri asuhan KH. Kholil Nawawi. Dia juga mengikuti pelatihan kader Aswaja di pesantren ini di bawah bimbingan KH. Khoiron Husain dan KH. Bashori Alwi pada tahun 1975 hingga 1977. Kemudian pada tahun 1995 sampai 1996 mengikuti pelatihan Program Pengembangan Wawasan Keulamaan (PPWK) yang diselenggarakan oleh Lakpesdam NU. Tahun 1996 juga dia mendapatkan ijazah ilmiah amah dari Sayyid Muhammad bin Alawi al-Maliki (Abdusshomad, 2015, p. 121, 2016, p. 395). Kiai Muhyiddin adalah salah seorang tokoh Aswaja NU, khususnya di Kabupaten Jember, yang juga menjadi Rais Syuriah PCNU Jember. 
Kiai Muhyiddin menulis beberapa buku. Hal ini pula yang menjadikannya sebagai patron (teladan) literasi, karena kehadiran karya-karya tersebut menunjukkan visi dan praktik literasi sang kiai. Setidaknya tercatat ada sepuluh karyanya: (1) "Fiqh Tradisonalis: Jawaban Pelbagai Persoalan Keagamaan Sehari-sehari" (terbit pertama kali pada 2004); (2) "Tahlil dalam Perspektif Alquran dan Hadis (Kajian Kitab Kuning)"; (3) "Hujjah NU, AkidahAmaliah-Tradisi," (terbit pertama kali pada 2008); (4) Al-Hujaj Al-Qath'iyyah fii Shihhah al-Mu'taqadaat Wa al-'Amaliyyaat alNahdliyyah"; (5) "Stop! Kekerasan terhadap Perempuan"; (6) "Aqidah Ahlussunnah Wal Jama'ah, Terjemah \& syarh Aqidah al- 'Awam"; (7) "Shalatlah seperti Rasulullah, Dalil Keshahihan Shalat ala ASWAJA" (terbit pertama kali pada 2011); (8) "Etika Pergaulan di Tengah Gelombang Perubahan (Kajian Kitab Kuning)"; (9) "Penuntun Qolbu (Kiat Meraih Kecerdasan Spiritual)"; (10) "Argumen Amaliyah di Bulan Sya'ban dan Ramadhan". Karya-karya yang penulis dapatkan hanya tiga, yakni buku nomor 1, 3, dan 7 .

Untuk kepentingan konteks pemikiran atau ideologi kiai sebagai sponsor atau patron, penulis fokuskan pada karya nomor 3 ("Hujjah NU, Akidah-Amaliah-Tradisi"). Hal ini karena karya buku tersebut benar-benar dapat mencerminkan pemikiran sang patron atau sponsor. Buku tersebut didesain dengan formal yang kecil dan tipis, yakni 121 halaman. Buku ini dibagi ke dalam tujuh bagian, dan merupakan semacam ringkasan dari buku pada nomor 1, yang berjudul "Fiqh Tradisonalis: Jawaban Pelbagai Persoalan Keagamaan Sehari-sehari." Tujuh bagian tersebut terdiri dari pembahasan tentang pemahaman tentang Aswaja, seputar persoalan bidah, sistem bermazhab, seputar ritual salat, menghormati nabi, penghormatan jenazah, dan beberapa persoalan lain seperti tawassul, mencium tangan ulama dan guru, hizib serta amalan. Sebagaimana judulnya, sesungguhnya buku ini memberikan argument tentang berbagai keyakinan, amaliyah, dan tradisi kalangan NU. Beberapa persoalan yang tegas berbeda dengan beberapa kelompok lain, yakni soal bermazhab, perayaan maulid Nabi dengan pembacaan kitab Barzanzi, tahlilan, tawasul, dan tarekat. Tujuan ditulisnya buku ini dengan jelas disampaikan penulisnya dalam bagian pengantar sebagai berikut.

Nawaitu penulis adalah semata-semata untuk memantapkan keshahihan akidah, amaliah dan tradisi kaum Nahdliyyin. Karena itu, berbagai persoalan yang diangkat dalam buku ini, penulis selalu merujuk kepada sumber-sumber primer ajaran Islam; Aal-Quran dan Hadits serta pendapat ulama yang mu'abar. Bahkan, penulis juga menukil pendapat-pendapat para ulama yang menjadi panutan kelompok yang mengingkari dan menolak amaliah dan tradisi NU. Hal ini dimaksudkan untuk meneguhkan apa yang telah diamalkan oleh kaum Nahdliyyin itu benar-benar dapat dipertanggungjawabkan secara ilmiah. Kendati demikian, kita harus mengembangkan sikap toleransi (tasamuh), dalam arti menghormati keyakinan orang lain tanpa harus menyetujuinya (Abdusshomad, 2015, p. v).

Kutipan di atas menunjukkan bahwa tujuan penulisan buku adalah benar-benar sebagai sebuah pertahanan argumen bagi tradisi keagamaan yang dilakukan kalangan NU. Oleh karena dapat dikatakan bahwa buku ini sedang mempertahankan suatu pemikiran ideologis (pemikiran yang sudah menjadi keyakinan), yakni Aswaja NU.

Karena sang patron atau sponsor memiliki pemikiran ini, tentu itu akan tercermin dalam produk-produk literasi yang dihasilkan, termasuk web. "Pesan-pesan sponsor ini" sendiri secara khusus muncul dalam salah satu menu web, yakni tausiyah pengasuh. Menu ini berisi berbagai pandangan-pandangan Kiai Muhyiddin-yang tentu sebagai sponsor literasi-yang sudah pernah dituangkan dalam buku-bukunya, termasuk dalam buku pertama dan ketiga yang telah dibahas, tetapi ada juga yang belum ditulis tetapi diungkapkan dalam suatu kesempatan. Pandangan-pandangan tersebut kemudian dituliskan kembali oleh redaksi web dan dituliskan rujukannya di bagian akhir tulisan (lihat contohnya pada link berikut: http://pesantrennuris.net/2018/11/30/pandanga n-ahlussunnah-tentang-musibah-perselisihanantara-sebagian-sahabat/). 
Selain dalam pandangan-pandangan yang terkumpul dalam rubrik atau menu tausiyah pengasuh, relasi patron/sponsor dan konteks pemikiran juga tampak dalam menu lainnya. Contoh yang jelas adalah pada menu Islamic Studies, terutama untuk tulisan Robith Qoshidi yang berjudul "Ahsunnah wal Jama'ah sebagai Kritik Sosial." Tulisan ini jelas sekali menggambarkan latar belakang pemikiran sponsor/patron dari produk literasi web.

Jadi bisa dikatakan, bahwa patronsponsor praktik literasi dalam konteks pesantren adalah kiai sebagai pengasuh, atau keluarga pengasuh yang dalam hal ini adalah putra-putra kiai. Hal tersebut kemudian mengingatkan tentang peran penting kiai dalam pesantren dan masyarakat. Pendidikan pesantren tidak mungkin bisa memisahkan pesantren dari kiai. Jika pesantren adalah dasar institusi masyarakat pesantren, maka kiai adalah inti sarinya. Kiai dapat membentuk identitas kolektif masyarakat pesantren, baik secara langsung maupun sebagaimana yang tampak dalam produk multiliterasi website. Kiai tetap menjadi pialang budaya yang menjadi semacam penyaring budaya dari luar sekaligus menjadi "juru biacara" pemikiran Islam yang dianut. Dalam konteks tulisan ini, kiai tetap menjadi semacam pialang budaya yang bertransformasi menjadi patron/sponsor praktik multiliterasi berbasis pesantren. Dengan demikian, kiai tetap berperan sebagai "penyaring budaya" di tengah era revolusi digital yang memerlukan multiliterasi khususnya dalam masyarakat pesantren.

Kuatnya peran patron serta sponsor juga sebetulnya ditunjukkan dalam beberapa peraturan terkait akses teknologi digital, seperti aturan akses gawai pintar, komputer, dan internet sebagaimana yang sudah dijelaskan pada bagian sebelumnya. "Hal itu semua dilakukan agar santri tetap fokus belajar dan sebisa mungkin terhindar dari sisi-sisi negatif gawai, komputer, internet" (wawancara dengan $\mathrm{Ab}$ dan B, 2/10/2018). Hal tersebut dikatakan oleh putra Kiai Muhyiddin. Jadi dari sini tampak bahwa kiai dan keluarganya yang ikut mengelola pesantren tetap memiliki peran penting sebagai "cultural broker" dalam konteks perkembangan teknologi digital.
Namun, di sisi lain, kiai juga menjadi patron dan sponsor praktik multiliterasi di pesantren.

Peran kiai sebagai patron dalam praktik multiliterasi di era digital ini, khususnya di Pondok Pesantren Nuris, dapat dilihat dalam dua hal berikut: Pertama, kiai tetap menjadi transformator perubahan, yakni kiai tetap mendukung perubahan-perubahan dan adaptasi dalam perkembangan teknologi digital. Hal ini ditunjukkan dengan dukungan kiai, baik moril maupun materil, dalam penggunaan beberapa perangkat teknologi digital pada sistem pembelajaran di pesantren. Kedua, kiai sebagai patron juga memberikan dasar spiritual, intelektual, dan ideologis, dalam praktik multiliterasi digital di pesantren, sehingga ia menjadi filter (penyaring) dalam konten-konten literasi digital bagi kalangan pesantren. Dengan demikian, kiai sebagai patron dalam praktik multiliterasi ini juga menunjukkan fungsi kiai dalam perkembangan teknologi digital, di satu sisi sebagai penggerak perubahan yang adaptif dalam perkembangan teknologi digital di pesantren, sehingga memunculkan praktik multiliterasi, tetapi di sisi lain juga menunjukkan penjaga tradisi, yakni menjaga nilai-nilai tradisi Aswaja sesuai latar belakang pemikiran keagamaan sang kiai.

\section{Respon Santri terhadap Pembelajaran Multiliterasi}

Pembelajaran multiliterasi di Pesantren Nuris direspon oleh para santri, yang dibuktikan dengan semua santri atau siswa di madrasahmadrasah pesantren mengikuti pembelajaran multiliterasi tersebut. Hanya saja, masingmasing santri memilih sendiri untuk benarbenar menekuni bidang tertentu sehingga mendapatkan porsi keikutsertaan dan perhatian lebih di kalangan para santri (wawancara dengan Ab, 2/10/2018). Misalnya, tidak semua santri terlibat secara penuh di ekstrakurikuler jurnalistik madrasah dan pesantren, hanya santri-santri tertentu yang memiliki minat untuk mendalami bidang jurnalistik. Begitu juga tidak semua siswa yang bergabung dalam ekstrakurikuler karya ilmiah remaja, tetapi hanya siswa tertentu saja yang ingin mendalami bidang tersebut. Hal yang sama juga terjadi untuk kegiatan-kegiatan keterampilan yang lain. Bidang yang diikuti semua santri dan siswa adalah kegiatan-kegiatan yang terkait dengan 
literasi agama, karena bidang literasi ini menjadi inti literasi di Pesantren Nuris.

Pembelajaran multiliterasi di pesantren tentu melibatkan infrastruktur yang diperlukan, seperti ketersediaan gawai, laptop, dan akses wifi. Seperti yang sudah dikemukakan di atas, semua perangkat dan jaringan wifi internet tersedia, meskipun dengan berbagai keterbatasan. Keterbatasan ini bukan karena pesantren tidak mau memenuhinya, tetapi ingin pesantren tetap memiliki aturan yang mendidik kedisiplinan santri (wawancara dengan $\mathrm{Ab}$, 2/10/2018). Beberapa santri yang sempat diwawancara juga menunjukkan respon yang positif tentang pembatasan-pembatasan penggunaan perangkat-perangkat di atas. Hal itu karena dalam waktu-waktu tertentu mereka tetap diperbolehkan untuk menggunakan perangkat-pengkat tersebut. Mereka sadar bahwa pembatasan-pembatasan tersebut adalah salah satu cara pengasuh mendidik kedisiplinan dalam belajar (wawancara dengan santri A, B, C, D, 3/10/2018).

\section{Kiai sebagai Patron dan Sponsor Praktik Multiliterasi}

Kajian tentang praktik literasi baru ini sesungguhnya ingin menempatkan konteks dan sponsor serta patron yang menumbuhkan praktik dan produk multiliterasi sebagaimana yang banyak juga dijelaskan oleh para ahli lain (Brandt, 2001, p. 19; Dewayani and Retnaningdyah, 2017, p. 44). Oleh karena itu, hal yang utama dijadikan perhatian dalam tulisan ini adalah aspek konteks dan patron/sponsor. Hal tersebut sesuai dengan tujuan penelitian dalam tulisan ini, yakni melihat peran atau representasi kiai dalam praktik multiliterasi. Kiai di sini dipandang sebagai patron dan sponsor dalam praktik multiliterasi. Karena kuatnya patron dan sponsor ini, maka respon santri dan orang tua cenderung menerima praktik pembelajaran multiliterasi yang dilakukan.

Temuan-temuan yang telah dipaparkan dalam tulisan ini menunjukkan bahwa praktik literasi bukanlah suatu yang otonom, tetapi merupakan suatu praktik yang kontekstual dan ideologis (Street, 2001; Dewayani and Retnaningdyah, 2017). Praktik literasi, dan multiliterasi melibatkan figur yang menjadi patron dan sponsor praktik tersebut (Brandt, 2001; Street, 2001). Figur tersebut memiliki latar belakang intelektual dan ideologis yang mendorong dipraktikan literasi dalam situasi tertentu (Gee, 2000), yakni situasi pesantren. Studi tentang praktik literasi di pesantren biasanya terkait dengan penggunaan kitab-kitab dan praktik pembelajaran (Lukens-Bull, 1970, 2000, 2001a; Dhofier, 1994). Studi dalam tulisan ini memberikan perspektif tentang peran kiai dalam praktik literasi di tengah perkembangan teknologi digital.

Tulisan ini telah membuktikan, pesantren tetap adaptif di tengah perkembangan teknologi digital, yang ditunjukkan dengan praktik multiliterasi. Hal ini didorong oleh seorang figur, yakni kiai. Kiai menjadi patron dan sponsor praktik multiliterasi di kalangan pesantren. Dengan menggunakan perspektif kajian literasi baru (Street, 2003; Barton dan Hamilton, 2005; Lankshear and Knobel, 2011), yang menekankan afiliasi konteks dan ideologis seorang patron praktik multiliterasi, tulisan ini memberikan pengetahuan tentang peran kiai dalam praktik multiliterasi belum banyak diperhatikan oleh para sarjana. Tulisan ini masih menerima pandangan bahawa kiai tetap sebagai figur penting dalam tradisi pesantren, tetapi tulisan ini melengkapi pandangan para ahli tersebut dengan mengajukan peran kiai sebagai patron dan sponsor praktik multiliterasi dalam pesantren.

\section{PENUTUP}

Website Pesantren Nuris mengindikasikan adanya kesadaran mengenai kepentingan pembelajaran multiliterasi. Website Pesantren Nuris hadir karena adanya pandangan tentang kebutuhan media digital yang dapat menjangkau pembelajaran multiliterasi karena variasi konten dan jangkauannya yang luas kepada masyarakat. Namun, hal itu juga tidak berarti para santri atau siswa bebas mengakses teknologi informasi digital setiap saat. Terdapat aturan-aturan tertentu sehingga santri tidak bebas seterusnya untuk mengakses teknologi digital. Begitu juga terdapat aturan-aturan untuk bisa mengakses jaringan internet.

Hal yang mendasari itu semua adalah patron dan sponsor praktik multiliterasi. Kiai 
sebagai patron dan sponsor praktik multiliterasi di pesantren menjadi konsep penting yang diajukan dalam tulisan ini. Patron dan sponsor praktik multiliterasi yang menghasilkan produk web adalah pengasuh dan keluarga pengasuh, yang dalam hal ini adalah kiai dan putra-putra kiai. Patron dan sponsor literasi senantiasa mewarnai konten dan penggarapan web atau produk multiliterasi apapun. Tulisan ini menunjukkan bahwa di zaman teknologi digital, kiai pesantren memegang posisi sebagai patron dan sponsor praktik multiliterasi berbasis pesantren. Visi dan pemikiran kiai akan memberikan pengaruh pada praktik literasi dan multiliterasi pesantren. Kiai akan menjadi teladan (patron) literasi sekaligus juga menjadi sponsor (unsur yang mendukung) praktik multiliterasi. Hal ini disebabkan oleh peran kiai yang tetap menjadi sentral pada lembaga pendidikan pesantren meskipun di era teknologi informasi dan media digital sekarang ini. Patron kiai sebagai pengasuh yang mengarahkan praktik pembelajaran multiliterasi direspon oleh para santri dengan kesadaran sebagai upaya mendidik kedisplinan dalam belajar.

Tulisan ini memberikan bukti tentang yang tetap dan yang berubah tentang peran kiai dalam praktik multiliterasi di tengah era teknologi digital. Hal yang tetap, sebagaimana pendapat para sarjana terdahulu, adalah bahwa kiai tetap menjadi cultural broker, sebagai penyaring budaya, dan penjaga tradisi pesantren dalam praktik multiliterasi di era digital. Sedangkan aspek yang berubah, dan belum banyak diulas oleh para sarjana, adalah tentang kiai sebagai patron praktik multiliterasi di era digital. Kecakapan multiliterasi di abad 21 harus dipenuhi oleh pesantren untuk menyiapkan para santri dalam menghadapi kompleksitas tantangan kehidupan di abad ini, dan oleh karena itu, kiai sebagai patron dan sponsor, tetap diperlukan sebagai figur mendorong praktik multiliterasi tersebut.

\section{UCAPAN TERIMAKASIH}

Tulisan ini didasarkan hasil penelitian yang didanai oleh DIPA Balai Litbang Agama Semarang tahun 2018. Oleh kaena itu, saya mengucapkan terima kasih kepada Kepala Balai Litbang Agama Semarang yang mengizinkan saya untuk melakukan penelitian ini. Saya juga mengucapkan terima kasih kepada para pihak yang telah memungkinkan jalannya penelitian ini, baik di Pesantren Nuris Jember, Kantor Kementerian Agama Kabupaten Jember, serta pihak-pihak tertentu, baik secara kelembagaan maupun individu yang membuat penelitian ini dapat berjalan.

\section{DAFTAR PUSTAKA}

Abdusshomad, M. (2015) Hujjah NU AkidahAmaliah-Tradisi. Malang: Pustaka Bayan.

Abdusshomad, M. (2016) Fiqh Tradisionalis: Jawaban Pelbagai Persoalan Keagamaan Sehari-hari. Malang: Pustaka Bayan.

Abidin, Y., Mulyati, T. and Yunansah, H. (2017a) 'Developing Literacy Learning Model Based On Multi Literacy, Integrated, and Differentiated Concept At Primary School', Cakrawala Pendidikan, 36(2), pp. 156-166. doi: :https://doi.org/10.21831/cp.v36i2.13283

Abidin, Y., Mulyati, T. and Yunansah, H. (2017b) Pembelajaran Literasi: Strategi Meningkatkan Kemampuan Literasi Matematika, Sains, Membaca, dan Menulis. Jakarta: Bumi Aksara.

Barton, D. and Hamilton, M. (2005) 'Literacy practices', in Barton, D., Hamilton, M., and Ivanic, R. (eds) Situated Literacies: Theorising Reading and Writing in Context. London and New York: Routledge, pp. 7-14. doi: 10.4324/9780203984963-10.

Beavis, C., Muspratt, S. and Thompson, R. (2015) "Computer games can get your brain working": student experience and perceptions of digital games in the classroom', Learning, Media and Technology, 40(1), pp. 21-42. doi: 10.1080/17439884.2014.904339.

Brandt, D. (2001) Literacy in American Lives. Cambridge: Cambridge University Press.

Burnett, N. et al. (2006) Education for All: Literacy for Life, UNESCO. Paris: UNESCO.

Chassiakos, Y. R. et al. (2016) 'Children and 
adolescents and digital media', Pediatrics, 138(5). doi: 10.1542/peds.2016-2593.

Dewayani, S. (2017) Menghidupkan Literasi di Ruang Kelas. Yogyakarta: Kanisius.

Dewayani, S. and Retnaningdyah, P. (2017) Suara dari Marjin: Literasi sebagai Praktik Sosial. Bandung: PT. Remaja Rosda Karya.

Dhofier, Z. (1994) Tradisi Pesantren, VI, Jakarta: LP3ES. Jakarta: LP3ES.

Gazali, E. (2018) 'Pesantren Di Antara Generasi Alfa Dan Tantangan', OASIS: Jurnal Ilmiah Kajian Islam, 2(2), pp. 96-109.

Gee, J. P. (2000) 'The New Literacy Studies: From "Socially Situated" to the Work of the Social', in Barton, D., Hamilton, M., and Ivanic, R. (eds) Situated Literacies: Reading and Writing in Context. London and New York: Routledge.

Halim, W. (2018) 'Young Islamic preachers on Facebook: Pesantren As'adiyah and its engagement with social media', Indonesia and the Malay World, 46(134), pp. 44-60. doi: 10.1080/13639811.2018.1416796.

Jamaludin, M. (2012) 'Metamorfosis Pesantern Di Era Globalisai', Journal of Social and Islamic Culture, 20(1), pp. 127-139.

Jewitt, C. (2008) 'Multimodality and literacy in school classrooms', Review of Research in Education, 32, pp. 241-267. doi: 10.3102/0091732X07310586.

Lankshear, C. and Knobel, M. (2011) New Literacies: Everyday Practices and Social Learning. 3rd edn. New York: Open University Press. doi: 10.1093/deafed/enj039.

Lewis, D. (2004) 'Children Reading Pictures: Interpreting Visual Texts', Literacy (formerly Reading), 38(1), pp. 65-66. doi: 10.1111/j.00340472.2004.03801011_1.x.

'Literasi Visual Tokoh Hanoman Bali dengan Pendekatan Augmented Reality' (2016) Journal Studi Kultural, II(1), pp. 42-47.

Lubis, M. A. et al. (2009) 'The application of multicultural education and applying ICT on Pesantren in South Sulawesi, Indonesia', WSEAS Transactions on Information Science and Applications, 6(8), pp. 1401-1411.

Lukens-Bull, R. A. (1970) 'Teaching Morality: Javanese Islamic Education in a Globalizing Era', Journal of Arabic and Islamic Studies. doi: 10.5617/jais.4554.

Lukens-Bull, R. A. (2000) 'The pesantren tradition: a study of the role of the kyai in the maintenance of the traditional ideology of Islam in Java', Journal of Asian Studies, 59(4), pp. 1091-1092. Available at: http://eresources.pnri.go.id:2073/docview/23041 9029/abstract.

Lukens-Bull, R. A. (2001a) 'Two Sides of the Same Coin: Modernity and Tradition in Islamic Education in Indonesia', Anthropology <html_ent glyph="@amp;" ascii="\&amp;"/> Education Quarterly, 32(3), pp. 350-372. doi: 10.1525/aeq.2001.32.3.350.

Lukens-Bull, R. A. (2001b) 'Two Sides of the Same Coin: Modernity and Tradition in Islamic Education in Indonesia', Anthropology \& Education Quarterly, 32(3), pp. 350-372. doi: 10.1525/aeq.2001.32.3.350.

Mansyur, M., Rahamma, T. and Fatima, J. M. (2013) 'Literacy Media Students Success Learning on Information and Communication Technology (ICT) In Junior High School 11 Par', Jurnal Komunikasi KAREBA, 2(4), pp. 379-385.

Marsh, J. (2011) 'Young Children's Literacy Practices in a Virtual World: Establishing an Online Interaction Order', Reading Research Quarterly, 46(2), pp. 101-118. doi: 10.1598/rrq.46.2.1.

Mastiyah, I. (2018) Pesantren, Iptek, da $n$ Multikulturalisme: Membaca Fenomena Ribuan Santri Berprestasi dan Moderat. Jakarta: UIN Jakarta Press.

Masyhur, F. (2016) 'The ICT Literacy Development Model for Farmers and Fishermen Community (Model Pengembangan Literasi TIK Masyarakat 
Tani dan Nelayan)', Journal Pekommas, 1(1), p. $101 . \quad$ doi: 10.30818/jpkm.2016.2010110.

Mills, K. A. (2010) 'Shrek Meets Vygotsky: Rethinking Adolescents' Multimodal Literacy Practices in Schools', Journal of Adolescent \& Adult Literacy, 54(1), pp. 35-45. doi: 10.1598/jaal.54.1.4.

Murtadlo, M. (2019) 'The Development of Scientific Writing Skills in Pesantren: a Comparative Analysis on Ma'Had Aly Sukorejo Situbondo and Ma'Had Aly Manggisan Wonosobo', Analisa: Journal of Social Science and Religion, 4(02), pp. 205-224. doi: 10.18784/analisa.v4i02.915.

Nasrullah, R. (2017) Media Sosial Pespektif Komunikasi, Budaya, dan Sosioteknologi. Bandung: Simbiosa Rekatama Media.

Pasadas, U. C. (2010) 'Multiliteracy and social networks in higher education', Revista de Universidad y Sociedad del Conocimiento, 7(2), pp. 16-25. doi: 10.7238/rusc.v7i2.978.

Street, B. (2003) 'What's "new" in New Literacy Studies?: Critical approaches to literacy in theory and practice', Current Issues in Comparative Education, 5(2), pp. 77-91.

doi: 10.1016/j.socscimed.2011.02.026.

Street, B. V (2001) 'Introduction', in Street, B. $\mathrm{V}$ (ed.) Literacy and Development: Ethnographic Perspective. New York: Routledge, pp. 21-26. Available at: http://ezproxy.lib.monash.edu.au/login?u $\mathrm{rl}=\mathrm{http}: / / \mathrm{www} . \mathrm{MONASH} . e b l i b . c o m . a u / E$ $\mathrm{BLWeb} /$ patron?target=patron\&extendedi $\mathrm{d}=\mathrm{P} \_178678 \_0 \&$.

Susilo, S. V. and Ramdiati, T. (2019) 'Penerapan Model Multiliterasi Untuk
Meningkatkan Keterampilan Menulis Karangan Persuasi Pada Mata Pelajaran Bahasa Indonesia Di Sekolah Dasar', Jurnal Cakrawala Pendas, 5(1). doi: 10.31949/jcp.v5i1.1199.

The London Group (1996) 'A pedagogy of multiliteracies: Designing social futures', Harvard Educational Review, 66(1), p. 60. doi: 10.17763/haer.66.1.17370n67v22j160u.

The Partnership for 21st Century Skills (2009) Framework for 21st century learning, P21 Partnership for 21st Century Learning. Bangkok. doi: http://www.21stcenturyskills.org/docume nts/framework_flyer_updated_jan_09_fi nal-1.pdf.

Trumbo, J. (1999) 'Visual literacy and science communication', Science Communication, 20(4), pp. 409-425. doi: $10.1177 / 1075547099020004004$.

Unsworth, L. (2002) 'Changing dimensions of school literacies', Australian Journal of Language and Literacy, 6(1).

World Economic Forum (2016) Digital Media and Society Implications in a Hyperconnected Era, World Economic Forum Shaping the Future Implications of Digital Media for Society project report. Available at: http://trends.ifla.org/files/trends/assets/ifl a-trend-reportexpert_meeting_synthesis_2013-0426.pdf.

Yanti, M. (2016) 'Determinan literasi digital mahasiswa: kasus Universitas Sriwijaya [Determinants of students digital literacy: the case of Sriwijaya University]', Buletin Pos dan Telekomunikasi, 14(2), p. 79. doi: 10.17933/bpostel.2016.140202. 